\title{
MENINGKATAN KETERAMPILAN MENULIS PUISI DENGAN MENGGUNAKAN MEDIA GAMBAR PADA MATA PELAJARAN BAHASA INDONESIA PESERTA DIDIK SEKOLAH DASAR
}

\author{
Asep Priatna ${ }^{1}$, Siti Nurhalimah ${ }^{2}$ \\ 1STKIP Subang, ${ }^{2}$ SDN Nugraha Pelita \\ 1aseppriatna064@gmail.com, ${ }^{2}$ sitinurhalimah330@gmail.com
}

\begin{abstract}
This research is motivated by the low skill of writing essays for grade 3 students in elementary school. Based on the observation results, the low ability of students in writing poetry on Indonesian language subjects is due to the lack of effective learning created by the teacher, ineffectiveness due to the inaccurate strategies applied by the teacher in learning. The research method used is Classroom Action Research (CAR). The reason for using this method is to find out how the use of picture media in improving poetry writing skills in this classroom action research was conducted on Indonesian language learning in SDN Layapan, Purwadadi District, Subang, 2017/2018 academic year in the first semester. Based on the results of the study concluded as follows: 1) Poetry writing skills using media images can be improved by means of; students observe images, explore their initial knowledge of images, write words that are appropriate to the image and develop ideas and ideas into whole poems by paying attention to the elements of poetry. The increase in poetry writing skills can be seen from the average value of students increasing from the initial conditions which only have an average value of 55 and in the first cycle of 63, cycle 2 the average value obtained by students is 72 . And then in the cycle III the average value obtained by students is 86 which is included in criterion A (very good); 2) Activity of students at the time of research using picture media for third grade students of SDN Layapan, showing an increase in writing skills for students. After doing the research as a whole the average value of students increases in cycle 1 the average value of students is 67 , then in the second cycle then in the second cycle the average value of students is 79 , and in the third cycle that is equal to 92 who can categorized as criterion $A$ (very good).
\end{abstract}

Keywords: Poetry Writing Skills, Image Media

\section{ABSTRAK}

Penelitian ini dilatarbelakangi oleh rendahnya ketereampilan menulis karangan pada siswa kelas 3 sekolah dasar. Berdasarkan hasil observasi 
rendahnya kemampuan peserta didik dalam menulis puisi pada mata pelajaran bahasa Indonesia disebabkan karena kurang efektifnya pembelajran yang diciptakan guru, ketidakefektifannya disebabkan karena kurang tepatnya strategi yang diterapkan oleh guru dalam pembelajaran. Metode penelitian yang digunakan yaitu Penelitian Tindakan Kelas (PTK). Alasan digunakan metode ini adalah untuk mengetahui bagaimana penggunaan media gambar dalam meningkatkan keterampilan menulis puisi di Penelitian tindakan kelas ini dilaksanakan pada pembelajaran bahasa Indonesia di SDN Layapan Kecamatan Purwadadi Kabupaten Subang tahun ajaran 2017/2018 pada semester pertama. Berdasarkan hasil penelitian diperoleh kesimpulan sebagai berikut : 1) Keterampilan menulis puisi menggunakan media gambar dapat ditingkatkan dengan cara; siswa mengamati gambar, menggali pengetahuan awalnya terhadap gambar, menuliskan kata-kata yang sesuai gambar dan mengembangkan ide beserta gagasannya ke dalam puisi utuh dengan memperhatikan unsur-unsur puisi. Peningkatan keterampilan menulis puisi tersebut nampak dari nilai rata-rata peserta didik meningkat dari kondisi awal yang hanya memiliki nilai rata-rata sebesar 55 dan pada siklus I sebesar 63, siklus 2 rata-rata nilai yang diperoleh peserta didik sebesar 72. Dan selanjutnya pada siklus III nilai rata-rata yang diperoleh peserta didik sebesar 86 yang termasuk pada kriteria A (sangat baik); 2) Aktivitas peserta didik pada saat penelitian dengan menggunakan media gambar pada peserta didik kelas III SDN Layapan, menunjukan adanya peningkatan keterampilan menulis pada peserta didik. Setelah dilakukan penelitian secara keseluruhan nilai ratarata peserta didik meningkat pada siklus 1 nilai rata-rata peserta didik yaitu 67 , selanjutnya pada siklus II selanjutnya pada siklus II nilai rata-rata peserta didik yaitu 79 , dan pada siklus III yaitu sebesar 92 yang bisa dikategorikan kriteria A (sangat baik).

Kata Kunci : Keterampilan Menulis Puisi, Media Gambar

\section{A. Pendahuluan}

Bahasa Indonesia lahir pada peristiwa sumpah pemuda tanggal 28 Oktober 1928. Peresmian bahasa Indonesia tersebut bermakna politis sebab bahasa Indonesia dijadikan sebagai alat perjuangan oleh kaum nasionalis (yang sekaligus bertindak sebagai perencana bahasa) untuk mencapai negara yang merdeka dan berdaulat. Peresmian ini juga menunjukan bahwa sebelum peristiwa sumpah pemuda, nama bahasa Indonesia sudah ada. Fakta sejarah menunjukan bahwa sebelum tahun 1928 telah ada gerakan kebangsaan yang menggunakan nama Indonesia dan dengan sendirinya pada mereka telah ada suatu konsep tentang bahasa Indonesia.

Menurut Kosasih dan Wawan (2012 : 1) dalam kedudukannya sebagai bahasa negara, bahasa Indonesia berfungsi sebagai : 1) 
Bahasa resmi kenegaraan; 2) Bahasa pengantar di dalam dunia pendidikan; 3) Alat perhubungan pada tingkat nasional unttuk kepentingan perencanaan dan pelaksanaan pembangunan nasional serta kepentingan pemerintah; dan 4) Alat pengembngan kebudayaan, ilmu pengetahuan dan teknologi.

Dunia pendidikan kini tengah menjadi fokus utama pemerintah. Hal ini disebabkan karena pendidikan memegang peranan penting dalam kelangsungan hidup bangsa dan negara. Pendidikan merupakan sarana untuk meningkatkan kualitas sumber daya manusia menjadi lebih baik dan unggul. Untuk mewujudkannya diperlukan jalur pendidikan yang meliputi pendidikan formal, informal dan nonformal. Jalur pendidikan adalah wahana yang dilalui peserta didik untuk mengembangkan potensi diri dalam suatu proses pendidikan yang sesuai dengan tujuan pendidikan. Pendidikan formal merupakan pendidikan yang diselenggarakan di sekolahsekolah pada umumnya. Jalur pendidikan ini mempunyai jenjang pendidikan yang jelas, mulai dari pendidikan dasar, pendidikan menengah, sampai pendidikan tinggi.
Sebenarnya pendidikan tidak hanya sebatas pendidikan formal di sekolah ataupun universitas, sejak kita lahir pun kita sudah mendapat pendidikan dari orang tua kita, misalnya pendidikan bagaimana bersikap, berjalan, serta hal-hal mendasar lainnya. Dirto Hadisusanto,dkk dalam (Dwi Siswoyo, 2007:24) menyatakan bahwa secara garis besar fungsi pendidikan itu ada tiga. Pertama, adalah menyiapkan sebagai manusia, kedua adalah untuk menyiapkan tenaga kerja, dan ketiga adalah untuk menyiapkan warga negara yang baik.

Pendidikan merupakan suatu proses yang sangat penting dan tidak bisa lepas dari kehidupan manusia. Sehingga, pendidikan ini harus terus berjalan untuk menjaga keberlangsungan hidup manusia, karena tanpa pendidikan tidak akan ada perpindahan ilmu pengetahuan serta nila-nilai dan norma sosial dari generasi tua ke generasi muda.

Undang-Undang Republik Indonesia No. 20 tahun 2003 pasal 1 tentang Sistem Pendidikan Nasional menjelaskan bahwa pendidikan adalah usaha sadar dan terencana untuk mewujudkan suasana belajar dan proses pembelajaran agar peserta didik secara aktif mengembangkan 
potensi dirinya untuk memiliki kekuatan spiritual keagamaan, pengendalian diri, kepribadian, kecerdasan, akhlak mulia, serta keterampilan yang diperlukan dirinya, masyarakat, bangsa dan negara.

Dalam pasal tersebut dijelaskan bahwa pengembangan potensi peserta didik merupakan tujuan utama. Dengan pengembangan berbagai potensi tersebut, diharapkan peserta didik siap untuk menghadapi tantangan perkembangan zaman. Luasnya persaingan di sektor kehidupanlah yang menuntut perkembangan peradaban pendidikan di Indonesia harus semakin maju.

Dalam menghadapi tantangan ini, setiap orang harus dibekali dengan mutu Sumber Daya Manusia (SDM) yang memadai. Pemerintah pun telah melakukan berbagai usaha untuk mewujudkan hal tersebut, misalnya saja pemberian Bantuan Operasional Sekolah (BOS) sampai perubahan kurikulum yang baru saja dilakukan belum lama ini. Dengan adanya usaha-usaha tersebut pemerintah berharap melalui jalur pendidikan akan berguna dalam pembekalan mutu Sumber Daya Manusia (SDM) Indonesia.
Melalui pendidikan peserta didik diharapkan akan memiliki mental kuat dan rasa percaya diri untuk mengembangkan keterampilannya, agar menjadi manusia yang kreatif dan berkualitas. Pengembangan keterampilan ini harus dimulai dari sekolah dasar dimana peserta didik akan terbiasa memahami sebuah konsep dalam ilmu pengetahuan. Sekolah Dasar merupakan jenjang dimana anak memperoleh pengalaman pertama. Selain itu jenjang sekolah dasar juga mengajarkan anak untuk berkomunikasi dengan orang lain. Untuk dapat berkomunikasi dengan orang lain maka anak memerlukan bahasa. Bahasa mengajarkan kita untuk memahami perasaan dan maksud yang disampaikan orang lain. Tidak terkecuali juga dengan pembelajaran Bahasa Indonesia, proses berkomunikasi sangatlah penting. Oleh karena itu,pembelajaran Bahasa Indonesia mengupayakan peningkatan kemampuan berkomunikasi secara lisan dan tertulis. Bahasa Indonesia yang terdiri atas empat keterampilan berbahasa (menyimak, membaca, berbicara, dan menulis) menjadi sebuah mata pelajaran yang aktif produktif. Artinya, dalam pembelajaran 
bahasa peserta didik tidak hanya berkutat pada konstrak teori bahasa, tetapi ditekankan pada sikap dan pemakaian bahasa yang kontekstual.

Salah satu bidang aktivitas yang memegang peranan penting dalam pembelajaran bahasa ialah menulis. Keterampilan menulis merupakan urutan yang terakhir dalam proses belajar bahasa setelah keterampilan menyimak, berbicara, dan membaca. Bila dibandingkan dengan ketiga keterampilan berbahasa lainnya, keterampilan menulis lebih sulit dikuasai. Hal ini karena diperlukan kemampuan untuk menguasai berbagai unsur kebahasaan dan unsur di luar bahasa itu sendiri yang akanmenjadi isi tulisan. Baik unsur bahasa maupun unsur ini harus saling berkaitan sehingga tulisan menjadi runtut dan terpadu. Menurut Canale dan Swaim (dalam Rofi'udin, 2001:193), keterampilan menulis dapat dipandang sebagai salah satu keterampilan berbahasa yang kompleks. Kegiatan menulis, paling tidak melibatkan aspek penggunaan bahasa dan pengolahan isi. Bahkan jika dipandang sebagai bagian kemampuan komunikatif, kegiatan menulis melibatkan kompetensi gramatikal, kompetensi sosio linguistik, kompetensi discourse/ wacana, dan kompetensi strategik.

H.G

Tarigan (1986)mengemukakan bahwa : Menulis sangat penting bagi pendidikan karena memudahkan peserta didik berpikir, dapat memudahkan kita merasakan dan menikmati hubungan-hubungan, memperdalam daya tanggap atau persepsi kita, memecahkan masalah-masalah yang kita hadapi, menyusun urutan bagi pengalaman. Tulisan dapat membantu kita menjelaskan pikiran-pikiran kita.

Menulis adalah suatu bentuk berfikir. Salah satu tugas dari tugas-tugas terpenting penting penulis sebagai penulis adalah menguasai prinsip-prinsip menulis dan berfikir, yang akan dapat menolongnya mencapai maksud dan tujuanya.Menulis berarti menyampaikan pikiran, perasaan, atau pertimbangan melalui tulisan. Alatnya adalah bahasa yang terdiri atas kata, frasa, klausa, kalimat, paragraph dan wacana. Pikiran yang disampaikan kepada oranglain harus dinyatakan dengan kata yang mendukung makna secara tepat dan sesuai dengan apa yang ingin dinyatakan. Makin teratur bahasa yang digunakan, makin mudah orang lain 
menangkap pikiran yang disalurkan melalui bahasa itu. Oleh karena iu, keterampilan menulis disekolah sangatlah penting.

Berpuisi bukanlah suatu kegiatan yang tidak dikenal, secara tidak disadari dalam mengungkapkan rasa kagum, rasa bangga, rasa kecewa orang bisa berpuisi. Dalam mengungkapkan menggunakan kata-kata yang dipilih, yang dipelihra. "Menulis puisi adalah kemampuan mengungkapkan gagasan pendapat dan perasaan kepada pihak lain dengan menggunakan bahasa tulis yang bersifat literer" (Depdiknas : 2003 : 8) ketepatan mengungkapkan gagasan harus didukung oleh ketepatan bahasa sastra yang digunakan. Selain komponen kosakata dan konteks kesastraan, ketetapan bahasa juga didukung oleh konteks dan penggunaan majas.

Keterampilan menulis ini tidak dapat datang tiba-tiba, tetapi dapat dicapai melalui proses belajar dan berlatih secara terus menerus. Menulis merupakan salah satu aspek keterampilan bahasa yang bersifat produktif dan ekspresif sehingga dapat dicapai dengan banyak latihan dan bimbingan yang intensif karena sifatnya yang bukan teoritis. Oleh karena itu, peranan guru sangat menentukan. Guru harus memiliki keterampilan menulis yang baik, di samping juga harus mampu mengajarkannya. Guru harus mampu merencanakan proses pembelajaran yang efektif. Metode dan media pembelajaran serta strategi belajar mengajar yang dipilih sangatlah berpengaruh terhadap hasil peserta didik.

Tujuan pembelajaran menulis tentulah mengharapkan para peserta didik memiliki kemampuan dalam menulis. Meskipun telah disadari, bahwa penguasaan bahasa tulis mutlak diperlukan dalam kehidupan modern, namun dalam kenayataannya pengajaran keterampilan menulis kurang mendapat perhatian.

Kegiatan menulis pada kenyataannya adalah hal yang tidak mudah. Ketika seseorang memiliki keinginan menulis namun tidak dapat melakukannya, hal tersebut disebabkan karena adanya keterlambatan dalam mengungkapkan gagasannya melalui bahasa yang baik dan benar. Apalagi untuk pembelajaran menulis puisi. Peserta didik mengalami kesulitan mengerjakan tugas menulis puisi karena kurang mampu mencari dan menggunakan katakata yang sesuai dengan bahasa puisi. Itu semua terjadi 
karena puisi lebih banyak mendayakan pengekspresian lewat berbagai ungkapan kebahasaan seperti berbagai bentuk pemajasan. Hal ini menunjukkan bahwa nilai keterampilan puisi rendah.

Dalam keseluruhan proses pendidikan, media pembelajaran memang memiliki peranan yang penting dalam proses belajar mengajar. Hal ini dapat diartikan bahwa berhasil dan tidaknya pencapaian tujuan pendidikan, cukup bergantung kepada bagaimana media pembelajaran yang digunakan. Oleh karena itu guru sebagai fasilitator harus mempunyai media yang tepat agar dapat menumbuh kembangkan potensi yang dimililiki peserta didik tersebut. Peserta didik merupakan subjek utama dalam kegiatan belajar mengajar, jadi sudah seharusnya potensi yang ada harus dikembangkan.

Melalui media pembelajaran yang tepat diharapkan dapat memperbaiki dan meningkatkan keterampilan peserta didik dalam menulis puisi. Melihat dari permasalahan yang ada, peneliti menetapkan langkah perbaikan dalam pembelajaran menulis puisi, salah satunya yaitu menggunakan media gambar. Dengan demikian, peserta didikakan terinspirasi dengan apa yang dilihat pada gambar. Media gambar pada keterampilan menulis puisi ini lebih menekankan keaktifan peserta didik untuk menggali dan mengekspresikan imajinasi dan pikirannya terhadap gambar yang dilihat. Sehingga melalui media gambar ini minat peserta didik menjadi lebih meningkat terhadap pembelajaran menulis puisi dengan menggunakan bahasa yang baik, benar, dan efektif.

Penelitian

tentang peningkatan keterampilan menulis puisi dengan menggunakan media gambar dilakukan karena melihat kondisi peserta didik menulis puisi belum sesuai dengan yang diharapkan. Peneliti memilih menulis puisi dengan menggunakan media gambar sebagai bahan kajian karena dalam media gambar peserta didik diajak dengan mengoptimalkan penglihatan terhadap gambar yang dilihatnya dan mengeksplorasi imajinasinya, kemudian dituangkan oleh peserta didik melalui kata-kata yang mengandung bahasa puisi. Hal ini sangat sesuai untuk pembelajaran menulis puisi karena dengan melihat gambar memudahkan peserta didik untuk menuangkan kata-kata dalam 
bahasa puisi dengan meliaht gambar secara nyata dan detail. Dengan kata lain, media gambar ini akan memudahkan peserta didik untuk menangkap ide-ide ke dalam tulisan.

Peneliti mengamati ada beberapa permasalahan tentang menulis puisi diatarannya adalah peserta didik menglami kesulitan menuangkan pikiran dan perasanya dalam bentuk puisi, kesulitan yang dihadapi peserta didik ditandai dengan beberapa hal seperti sulit menemukan ide, menemukan kata pertama dalam puisinya, mengembangkan ide menjadi puisi karena minimnya penggunaan kosa kata, dan tidak terbisa mengemukakan perasaan, pemikiran, dan imajinasi.

Berdasarkan hasil observasi rendahnya kemampuan peserta didik dalam menulis puisi pada mata pelajaran bahasa Indonesia disebabkan karena kurang efektifnya pembelajran yang diciptakan guru, ketidakefektifannya disebabkan karena kurang tepatnya strategi yang diterapkan oleh guru dalam pembelajaran. Dari hasil observasi yang dilakukan peneliti di SDN Layapan kelas III Sekolah Dasar masih kurang karena dari 27 peserta didik masih ada 22 peserta didik yang belum mencapai ketuntasan dengan nilai ketuntasan KKM 65. Hal ini menandakan bahwa keterampilan menulis puisi masih sangat rendah. Dari permasalahan-permasalahan

diatas maka perlu suatu pembelajaran yang dapat meningkatkan keterampilan menulis puisi salah satunya dengan media gambar.

\section{B. Metode Penelitian}

Menurut Sanjaya (Novianti, 2015 : 46) "Penelitian tindakan kelas (PTK) merupakan salah satu upaya yang dapat dilakukan guru untuk meningkatkan kualitas peran dan tanggng awab guru khususnya dalam pengelolaan pembelajaran." Melalui PTK, guru dapat meningkatkan kinerjanya secara terus menerus, dengan cara melakukan refleksi diri, yakni upaya menganalisis untuk menemukan kelemahan-kelemahan dalam proses pembelajaran yang dilakukannya, kemudian merencnakan untuk proses perbaikan serta mengimplementasikanya dalam proses pembelajaran sesuai dengan program pembelajaran yang telah disusunya, dan diakhiri dengan melakukan refleksi. PTK merupakan dari kemampuan 
professional guru, PTK merupakan kegiatan ilmiah yakni proses berfikir yang sistematis dan empiris dalam upaya memecahkan masalah. Proses pembelajaran yang dihadapi oleh guru dalam melaksanakan tugas utamanya yaitu mengajar.

Instumen penelitian adalah suatu alat yang digunakan untuk mengumpulkan data penelitian. Karanena alat dan instrumen ini mencerminan jauga cara pelaksanaanya. Menurut Sanjaya (Novianti, 2015 : 54). Dalam PTK rbanyak instrumen yang dapat digunakan untuk mengumpulkan data, namun penggunaanya sangat tergantung kepada jenis permasalahan yang akan diteliti.

Penelitian tindakan kelas ini dilaksanakan pada pembelajaran bahasa Indonesia di SDN Layapan Kecamatan Purwadadi Kabupaten Subang tahun ajaran 2017/2018 pada semester pertama. Dasar pertimbangan dijadikan lokasi atau tempat penelitian karena peserta didik layak dijadikan subjek penelitian dalam keterampilan menulis puisi masih rendah.

Adapun yang menjadi subjek penelitian kelas ini adalah peserta didik kelas III SDN Layapan yang berjumlah 27, yang terdiri dari 14 laki-laki dan 13 perempuan.

\section{Hasil Penelitian dan Pembahasan}

\section{Hasil Kondisi Awal}

Tes pada kondisi awal merupakan keterampilan menulis puisi sebelum dilakukan tindakan penelitian. Tes keterampilan ini bertujuan untuk mengetahui kondisi awal keterampilan menulis puisi siswa kelas III SDN Layapan. Jumlah siswa yang mengikuti tes pada kondisi awal ini adalah 27 orang, Pengamatan ini dilakukan dengan memberikan tes awal (Pretest) berupa soal kepada siswa sebanyak 30 butir soal pilihan ganda. Berikut (Pretest) berupa soal kepada siswa sebanyak 30 butir soal pilihan ganda. Berikut hasil presentase tes awal (Pretest) yang telah dilakukan pada siswa kela III SDN Layapan. Berdasarkan studi pendahuluan hasil tes keterampilan menulis puisi pra siklus menunjukan bahwa masih banyak peserta didik yang belum mencapai nilai kriteria ketuntasan minimal (KKM) yang sudah ditetapkan yaitu 65 , nilai yang dinyatakan lulus sebanyak 5 orang peserta didik dengan persentase $19 \%$ dan yang belum lulus sebanyak 22 orang peserta didik 
dengan persentase $81 \%$ dengan rata-rata yang diperoleh adalah 56,48 . Nilai rata-rata tersebut diperoleh dari hasil tes keterampilan menulis puisi. Penilaian hasil keterampilan menulis puisi diperoleh dari hasil kolaborasi antara peneliti dan guru kelas III. Dari hasil data awal diatas dapat disimpulkan bahwa keterampilan menulis puisi peserta didik kelas III SDN Layapan masih sangat kurang.

\section{Siklus 1}

a. Hasil Tes Keterampilan Menulis Puisi Siklus I Pertemuan 1

Hasil tes peserta didik pada pembelajaran keterampilan menulis puisi Bahasa Indonesia dengan menggunakan media gambar yang dilaksanakan pada siklus I pertemuan 1, menunjukan bahwa hasil tes keterampilan menulis puisi siklus I pertemuan 1 menunjukan bahwa peserta didik dengan nilai yang dinyatakan lulus sebanyak 8 dengan persentase $30 \%$, dan yang tidak lulus sebanyak 19 dengan persentase $70 \%$, dengan rata-rata kelas yang diperoleh adalah 63 dengan kategori kurang. Hal ini menunjukan bahwa keterampilan menulis puisi masih kurang.
Berdasarkan hasil siklus I bahwa keterampilan menulis puisi peserta didik mulai meningkat dalam aspek menentukan judul, diksi, kreativitas ide, keterpaduan keseluruhan isi dan bahasa figurative/gaya bahasa Dimana hanya terdapat 4 orang atau $15 \%$ yang termasuk kategori baik, 6 orang peserta didik atau $22 \%$ yang termasuk kategori cukup, dan 17 orang peserta didik atau $63 \%$ yang termasuk kategori kurang. Dari data diatas dapat dilihat bahwa keterampilan menulis puisi peserta didik kela III SDN Layapan mulai meningkat dengan kategori cukup, setelah peserta didik diberikan dengan menggunakan media dalam menulis puisi.

\section{b. Hasil Tes Keterampilan Menulis Puisi Siklus I Pertemuan 2}

Hasil tes peserta didik pada pembelajaran keterampilan menulis puisi Bahasa Indonesia dengan menggunakan media gambar yang dilaksanakan pada siklus I pertemuan 2 menunjukan bahwa peserta didik dengan nilai yang dinyatakan lulus sebanyak 12 dengan persentase $44 \%$, dan yang tidak lulus sebanyak 15 dengan persentase $56 \%$, dengan rata-rata 
kelas yang diperoleh adalah 66 dengan kategori cukup. Hal ini menunjukan bahwa keterampilan menulis puisi peserta didik mulai meningkat. Pada siklus I pertemuan 2 diatas bahwa keterampilan menulis puisi peserta didik mulai meningkat dalam aspek menentukan judul,diksi,kreativitas ide, keterpaduan keseluruhan isi dan bahasa figuratif/gaya bahasa. Dimana hanya terdapat 3 orang atau $11.11 \%$ yang termasuk kategori baik, 9 orang peserta didik atau 33,33 \% yang termasuk kategori cukup, dan 15 orang peserta didik atau $46 \%$ yang termasuk kategori kurang. Dari data diatas dapat dilihat bahwa keterampilan menulis puisi peserta didik kela III SDN Layapan mulai meningkat dengan kategori cukup, setelah peserta didik diberikan dengan menggunakan media gambar dalam menulis puisi.

\section{Siklus II}

\section{a. Hasil Tes Keterampilan Menulis Puisi Siklus II Pertemuan 1}

Hasil tes peserta didik pada pembelajaran keterampilan menulis puisi Bahasa Indonesia dengan menggunakan media gambar yang dilaksanakan pada siklus II pertemuan 1 menunjukan bahwa hasil tes keterampilan menulis puisi siklus II pertemuan 1 menunjukan bahwa peserta didik dengan nilai yang dinyatakan lulus sebanyak 15 dengan persentase $56 \%$, dan yang tidak lulus sebanyak 12 dengan persentase $44 \%$, dengan rata-rata kelas yang diperoleh adalah 69 dengan kategori cukup. Hal ini menunjukan bahwa keterampilan menulis puisi peserta didik mulai meningkat. Pada siklus I menunjukan bahwa keterampilan menulis puisi peserta didik mulai meningkat dalam aspek menentukan judul, diksi, kreativitas ide, keterpaduan keseluruhan isi dan bahasa figurative/gaya bahasa Dimana hanya terdapat 6 orang atau $22.22 \%$ yang termasuk kategori baik, 9 orang peserta didik atau $33.33 \%$ yang termasuk kategori cukup, dan 12 orang peserta didik atau $44.45 \%$ yang termasuk kategori kurang. Dari data diatas dapat dilihat bahwa keterampilan menulis puisi peserta didik kela III SDN Layapan mulai meningkat dengan kategori cukup, setelah peserta didik diberikan dengan menggunakan media dalam menulis puisi. 
b. Hasil Tes Keterampilan

Menulis Puisi Siklus II

\section{Pertemuan 2}

Hasil tes peserta didik pada pembelajaran keterampilan menulis puisi Bahasa Indonesia dengan menggunakan media gambar yang dilaksanakan pada siklus II pertemuan 2, menunjukan hasil tes keterampilan menulis puisi siklus II pertemuan 2 menunjukan bahwa peserta didik dengan nilai yang dinyatakan lulus sebanyak 17 dengan persentase $63 \%$, dan yang tidak lulus sebanyak 10 dengan persentase $37 \%$, dengan rata-rata kelas yang diperoleh adalah 72 dengan kategori cukup. Hal ini menunjukan bahwa keterampilan menulis puisi peserta didik mulai meningkat. Berdasarkan hasil siklus II pertemuan 2 diatas bahwa keterampilan menulis puisi peserta didik mulai meningkat dalam aspek menentukan judul,diksi,kreativitas ide, keterpaduan keseluruhan isi dan bahasa figuratif/gaya bahasa. Dimana hanya terdapat 1 orang atau 3.3\% yang termasuk kategori sangat baik, 9 orang peserta didik atau 33,33 \% yang termasuk kategori baik, 7 orang peserta didik atau $26 \%$ yang termasuk kategori cukup dan 10 orang peserta didik atau $37.37 \%$ yang termasuk kategori kurang. Dari data diatas dapat dilihat bahwa keterampilan menulis puisi peserta didik kela III SDN Layapan mulai meningkat dengan kategori cukup, setelah peserta didik diberikan dengan menggunakan media dalam menulis puisi.

\section{Siklus III}

\section{a. Hasil Tes Keterampilan} Menulis Puisi Siklus III Pertemuan1

Hasil tes peserta didik pada pembelajaran keterampilan menulis puisi Bahasa Indonesia dengan menggunakan media gambar yang dilaksanakan pada siklus III pertemuan 1 , hasil tes keterampilan menulis puisi siklus III pertemuan 1 menunjukan bahwa peserta didik dengan nilai yang dinyatakan lulus sebanyak 23 dengan persentase $85 \%$, dan yang tidak lulus sebanyak 4 dengan persentase $15 \%$, dengan rata-rata kelas yang diperoleh adalah 79 dengan kategori Baik. $\mathrm{Hal}$ ini menunjukan bahwa keterampilan menulis puisi peserta didik mulai meningkat.

Berdasarkan pada hasil siklus 1 pertemuan 1 bahwa keterampilan menulis puisi peserta didik mulai meningkat dalam aspek 
menentukan judul, diksi, kreativitas ide, keterpaduan keseluruhan isi dan bahasa figurative/gaya bahasa Dimana hanya terdapat 4 orang atau $15 \%$ yang termasuk kategori sangat baik, 15 orang peserta didik atau $55 \%$ yang termasuk kategori baik, 4 orang peserta didik atau 15 $\%$ yang termasuk kategori cukup. Dan 4 orang peserta didik atau 15\% termasuk kategori kurang. Dari data diatas dapat dilihat bahwa keterampilan menulis puisi peserta didik kela III SDN Layapan meningkat dengan menggunakan media dalam menulis puisi.

\section{b. Hasil Tes Keterampilan \\ Menulis Puisi Siklus III Pertemuan2}

Hasil tes peserta didik pada pembelajaran keterampilan menulis puisi Bahasa Indonesia dengan menggunakan media gambar yang dilaksanakan pada siklus II pertemuan 2 diperoleh hasil tes keterampilan menulis puisi siklus III pertemuan 2 menunjukan bahwa peserta didik dengan nilai yang dinyatakan lulus sebanyak 27 peserta didik dengan persentase $100 \%$, dengan rata-rata nilai kelas yang diperoleh adalah 86 dengan kategori sangat baik. Hal ini menunjukan bahwa keterampilan menulis puisi peserta didik sudah meningkat.

Berdasarkan hasil siklus III pertemuan 2 diatas bahwa keterampilan menulis puisi peserta didik mulai meningkat dalam aspek menentukan judul,diksi,kreativitas ide, keterpaduan keseluruhan isi dan bahasa figuratif/gaya bahasa. Dimana terdapat 8 orang atau $30 \%$ yang termasuk kategori sangat baik, 16 orang peserta didik atau $59 \%$ yang termasuk kategori baik, dan 3 orang peserta didik atau $11 \%$ yang termasuk kategori cukup. Dari data diatas dapat dilihat bahwa keterampilan menulis puisi peserta didik kela III SDN Layapan meningkat dengan menggunakan media dalam menulis puisi.

Selanjutnya untuk mengetahui adanya peningkatan belajar maka peneliti melakukan uji Posttest kepada siswa dengan memberikan 30 soal pilihan ganda sama dengan Pretest. Dari hasil data akhir dapat disimpulkan bahwa keterampilan menulis puisi peserta didik kelas III SDN Layapan sangatbaik. Untuk lebih jelasnya, hasil tes keterampilan menulis pada kondisi akhir menunjukan bahwa siswa yang lulus yaitu sebanyak 
$100 \%$ siswa, atau keseluruhan siswa.

\section{Keterampilan Menulis Puisi Pada Peserta Didik}

Pembelajaran untuk meningkatkan keterampilan menulis puisi pada peserta didik dilakukan dengan menerapkan media gambar pada pelajaran bahasa Indonesia yang dilaksanakan di SDN Layapan. Pada pelaksanaan tindakan keterampilan menulis puisi pada peserta didik mengalami peningkatan.

Dari hasil penelitian dapat dijelaskan bahwa perolehan nilai rata-rata peserta didik pada data awal sebesar 55 , setelah diberikan tindakan pada siklus I pertemuan 1 perolehan nilai rata-rata peserta didik meningkat menjadi 63 , dan siklus I pertemuan 2 perolehan nilai rata-rata peserta didik meningkat menjadi 66. Peningkatan nilai belum terlalu tinggi karena peserta didik masih merasa kebingungan dengan penerapan media gambar yang telah diterapkan oleh peneliti, selanjutnya pada siklus II pertemuan 1 peserta didik mengalami peningkatan dengan nilai rata-rata menjadi 69 , dan siklus II pertemuan 2 perolehan nilai rata-rata peserta didik meningkat menjadi $72 \%$. Dari data diatas dapat disimpulkan bahwa nilai rata-rata peserta didik meningkat, selanjutnya pada siklus III pertemuan 1 nilai rata-rata peserta didik mengalami peningkatan menjadi $79 \%$, dan siklus III pertemuan 2 nilai rata-rata peserta didik meningkat menjadi 86\%, Dan terakhir yaitu Posttes, nilai rata-rata postes adalah 95 . Maka dapat disimpulkan bahwa nilai rata-rata peserta didik mengalami peningkatan.

Berdasarkan hasil penelitian dapat dijelaskan bahwa adanya peningkatan nilai ketuntasan pada peserta didik, dilihat dari data awal peserta didik yang mencapai nilai KKM hanya berjumlah 5 orang, lalu pada siklus I pertemuan 1 yaitu sebanyak 8 orang, siklus 1 pertemuan 2 yaitu sebanyak 12 orang, siklus II pertemuan 1 yaitu sebanyak 15 orang, siklus II pertemuan 2 yaitu sebanyak 17 Orang, siklus III pertemuan 1 yaitu sebanyak 23 orang dan siklus III pertemuan 2 yaitu sebanyak 27 orang, dan hasil akhir setelah siswa mengerjakan soal posttest siswa yang mencapai KKM yaitu sebanyak 31 orang. Dengan 
demikian jumlah ketuntasan pada peserta didik mengalami kenaikan pada setiap siklusnya. Dilihat dari ketuntasan klasikalnya mengalami peningkatan.

Berdasarkan hasil penelitian perbandingan nilai klasikal mulai dari data awal nilai klasikal mulai dari data awal nilai klasikalnya $19 \%$, setelah peneliti menerapkan media gambar pada pembelajaran menulis puisi nilai klasikal pada siklus I pertemuan 1 mengalami peningkatan yaitu $30 \%$, siklus 1 pertemuan 2 yaitu 44\%, siklus II pertemuan 1 yaitu $56 \%$,siklus II pertemuan 2 yaitu $63 \%$, pada siklus III pertemuan 1 yaitu $85 \%$ dan siklus III pertemuan 2 yaitu menjadi $100 \%$, dan nilai akhir post test $100 \%$.

\section{Kesimpulan}

Berdasarkan hasil penelitian mengenai "meningkatkan keterampilan menulis puisi dengan menggunakan media gambar pada pelajaran bahasa Indonesia sekolah dasar". Dapat disimpulkan sebagai berikut :

1. Keterampilan menulis puisi menggunakan media gambar dapat ditingkatkan dengan cara; siswa mengamati gambar, menggali pengetahuan awalnya terhadap gambar, menuliskan kata-kata yang sesuai gambar dan mengembangkan ide beserta gagasannya ke dalam puisi utuh dengan memperhatikan unsur-unsur puisi. Peningkatan keterampilan menulis puisi tersebut nampak dari nilai rata-rata peserta didik meningkat dari kondisi awal yang hanya memiliki nilai rata-rata sebesar 55 dan pada siklus I sebesar 63, siklus 2 rata-rata nilai yang diperoleh peserta didik sebesar 72. Dan selanjutnya pada siklus III nilai rata-rata yang diperoleh peserta didik sebesar 86 yang termasuk pada kriteria $\mathrm{A}$ (sangat baik).

2. Aktivitas peserta didik pada saat penelitian dengan menggunakan media gambar pada peserta didik kelas III SDN Layapan, menunjukan adanya peningkatan keterampilan menulis pada peserta didik. Setelah dilakukan penelitian secara keseluruhan nilai ratarata peserta didik meningkat pada siklus 1 nilai rata-rata peserta didik yaitu 67, selanjutnya pada siklus II selanjutnya pada siklus II nilai 
rata-rata peserta didik yaitu 79 , dan pada siklus III yaitu sebesar 92 yang bisa dikategorikan kriteria A (sangat baik).

\section{DAFTAR PUSTAKA}

Kosasih, E. dan Wawan H. (2012). Bahasa Indonesia Berbasis Kepenulisan

Karya IImiah dan Jurnal. Bandung: CV Thursina.

Siswoyo, Dwi. (2007). IImu Pendidikan. Yogyakarta: UNY Pers

Rofi'uddin, Ahmad, Darmiyati, Zuhdi.(2002). Pendidikan Bahasa dan Sastra. Indonesia di Kelas Tinggi. Malang: Universitas Negeri Malang.

Tarigan, H. G. (1986). Menulis Sebagai Suatu Keterampila Berbahasa. Bandung: Angkasa.

Depdiknas. (2003). Kurikulum 2004 Standar Kompetensi. Jakarta: Puskur. Dit. PTKSD.

Depdiknas .(2003). Undangundang $R I$ No.20 tahun 2003.tentang sistem pendidikan nasional. Jakarta : Depdiknas. 